\title{
Epopeia e religião: fronteiras entre mito e história
}

Christina Ramalho ${ }^{1}$

http://orcid.org/0000-0002-8298-698X http://lattes.cnpq.br/8101223822887992

Recebido em: 22/10/2018

Aceito em: 20/02/2019

\begin{abstract}
Resumo: Estudo da presença de Deus e de Jesus em epopeias estrangeiras e brasileiras, a saber: $A$ saga de Mem de Sá, Memorial da infancia de Cristo e Triunfo do Divino Amor, Anchieta ou O evangelho nas selvas, Christ e $A$ cabeça calva de Deus, com o intuito de observar o modo como as fronteiras entre mito e história foram trabalhadas em poemas épicos religiosos ou de contaminação religiosa, com destaque para a importância do plano literário como agente de releitura de imagens míticas religiosas e de reinvenção da própria história. Espera-se também, com este breve estudo, contribuir para a constatação da permanência do épico como materialidade da arte literária em que mito e história ganham aderência através do heroísmo épico, resultando em expressões de importante caráter cultural, por revelarem pontos de vista que traduzem a experiência humano-existencial através dos tempos e dos espaços.
\end{abstract}

Palavras-chave: Epopeia; Religião; Mito; História.

Abstract: Study of the presence of God and Jesus in foreign and Brazilian epic poetry, namely: The Saga of Mem de Sa, Christ's Childhood Memorial and Triumph of Divine Love, Anchieta or The Gospel in the Jungles, Christ and The bald head of God, in order to observe how the boundaries between myth and history were worked out in religious epic poems or poems with religious contamination, with emphasis on the importance of the literary plan as an agent for re-reading mythical religious images and reinvention of history itself. It is also hoped, with this brief study, to contribute to the discovery of the permanence of the epic as a materiality of literary art in which myth and history gain adherence through epic heroism, resulting in expressions of important cultural character, for revealing points of view that translate the human-existential experience through times and spaces.

Keywords: Epic poetry; Religion; Myth; History.

\section{Introdução}

Neste texto não abordarei, específica ou teoricamente, o gênero épico, visto que esforços como os de Anazildo Vasconcelos da Silva, Saulo Neiva, Jean-Pierre Martin, Florence Goyet, Claudine Le Blanc ${ }^{2}$, os meus próprios, entre muitos outros nomes, já garantiram o resgate desse gênero, fato também facilmente comprovável a partir do acesso ao Centro Internacional e Multidisciplinar de Estudos Épicos (CIMEEP/UFS) ${ }^{3}$, no qual mais de 80

\footnotetext{
${ }^{1}$ Professora Adjunta 4 do Curso de Letras da Universidade Federal de Sergipe, campus Itabaiana. Doutora em Letras (UFRJ, 2004), com Pós-Doutorado em Estudos Cabo-Verdianos (USP/FAPESP, 2012) e em Estudos Épicos (Université Clermont-Auvergne, 2017). Site: www.ramalhochris.com .

E-mail: ramalhochris@hotmail.com.

${ }^{2}$ Encontra-se em elaboração o livro Goyet e Le Blanc: teoria e crítica francesas sobre o gênero épico, em que discorrerei, com o recurso da entrevista e da tradução comentada, sobre as contribuições teóricas e críticas das pesquisadoras e docentes Florence Goyet (Université Grenoble Alpes) e Claudine Le Blanc (Universite Sorbonne Nouvelle 3 - Paris 3).

${ }^{3}$ www.cimeep.com
} 
membros, de universidades de diversas partes do mundo, revelam as inúmeras pesquisas desenvolvidas e em desenvolvimento sobre o épico, suas derivações, transformações e hibridismos. O mesmo se pode descobrir no site do Réseau Euro-Africain de recherches sur les Epopées (REARE) 4 ou no do Projet Épopée/Recueil Ouvert5, ambos importantes veiculadores de pesquisas sobre o épico, coordenados, respectivamente, por Claudine Le Blanc e Florence Goyet.

Sendo assim, o estudo aqui apresentado partirá do épico como uma existência incontestável para sondar, em algumas obras exemplares, as medidas da presença da religião em uma realização literária marcada pela fusão entre os planos histórico e maravilhoso que, necessariamente, ela contém. Ainda que a incursão seja breve, dadas as dimensões amplas que qualquer epopeia, por si só, apresenta, creio ser interessante indicar algumas pistas sobre o modo como história e mito são entrelaçados em epopeias religiosas ou naquelas em que a presença da religião ou de elementos místicos se verifica.

Falar em religião, desde o próprio termo, já significa entrar no campo da pluralidade. Talvez o ideal fosse recorrer ao termo "religiosidades", visto que há muitas religiões, e, com elas, diferentes conceitos de divindade, ritual, fé, moralidade, etc. surgem, acompanhados de práticas igualmente diversas. Também pareceria mais adequado partir do termo "sagrado" e aqui me surge uma colocação de Roger Caillois, em seu famoso livro O homem e o sagrado (1979), cujo original, L'Homme et le Sacré, data de 1950:

Qualquer concepção religiosa do mundo implica a distinção do sagrado e do profano, opõe ao mundo em que o fiel se entrega livremente às suas ocupações, exerce uma atividade sem consequências para a sua salvação, um domínio onde o temor e a esperança o paralisam, alternadamente, onde, como à beira de um precipício, o mínimo desvio no mínimo gesto pode perdelo irremediavelmente (1979, p.19).

A partir do que Caillois assinala, o sagrado, como fonte de uma estruturação religiosa que fundamenta o comportamento humano, está presente em qualquer concepção religiosa. Ainda segundo ele, "é do sagrado, com efeito, que o crente espera todo o socorro e todo o êxito" (1979, p.22) e "para quem decida recorrer a ela [referência à energia do sagrado] ${ }^{6}$, o problema consiste em captá-la e utilizá-la da melhor maneira possível para os seus interesses" (Ibidem). Todas essas colocações pressupõem um "agente", cuja atuação se subordina ao sagrado como limite. E esse limite é, em cada religião, definido e normativamente traçado a partir do próprio modo como cada uma entende e sistematiza a vivência desse sagrado.

Compreendida a relação entre o sagrado e as religiosidades possíveis, e também constatada a necessidade da existência de agentes que, através de ritos específicos, colocarão em prática uma normatização específica do sagrado a partir de uma religião ${ }^{7}$, podemos pensar - e aqui já apresento um dos questionamentos que surgem a partir da proposta de análise apresentada - em que medida se poderia associar a ideia de "crente" à autoria épica, ou em outras palavras: a presença da religião em uma epopeia define, por parte de seu autor ou de sua autora, de certo modo, uma "captação" e uma "utilização" da "energia do sagrado" em prol de um interesse ideológico?

Voltando à questão das nomeações possíveis (religião, religiosidades, sagrado,

\footnotetext{
${ }^{4}$ https:// reare.univ-rouen.fr/qui-sommes-nous.

${ }^{5}$ http://ouvroir-litt-arts.univ-grenoble-alpes.fr/revues/projet-epopee/.

${ }^{6}$ Grifo meu.

${ }^{7}$ Não entrarei aqui, por motivos de espaço, na distinção entre religião e seita.
} 
misticismo), explico que o termo "religião" do título acaba por se tornar mais pertinente, visto que as análises a serem desenvolvidas envolverão imagens míticas bíblicas e, por isso, mais específicas, o que não denota que outras formas de religiosidade e religião não estejam presentes em obras épicas. Sim, estão. No entanto, dada a contundente presença do Judaísmo e do Cristianismo (Catolicismo e Protestantismo) nas epopeias ocidentais, busquei concentrar-me em cinco epopeias, a saber: A saga de Mem de Sá (séc. XVI), Memorial da infância de Cristo e Triunfo do Divino Amor (séc. XVII), Anchieta ou O evangelho nas selvas (séc. XIX), Christ (séc. XX) e A cabeça calva de Deus (séc. XXI), de autores e nacionalidades diversas, como se verá mais adiante, para discutir, especificamente, as relações entre as imagens míticas de "Deus" e de "Jesus Cristo" e as configurações dos planos histórico e mítico nessas obras.

Finalizo esta introdução lembrando, contudo, que essas duas imagens, ao se presentificarem em epopeias, denunciam de imediato o uso da intertextualidade com o texto bíblico, o que, segundo Salma Ferraz, nada tem de estranho, visto que: "A Bíblia está entre os maiores best-sellers de todos os tempos e é uma obra clássica da literatura hebraica e cristã, imprescindível para o conhecimento do cristianismo, da Literatura Ocidental e da cultura do Ocidente" (2008, p.21). E mais: "Não existe Ocidente sem a ideia de Deus" (Ibidem) e "jamais, em todo o tempo, pesquisou-se, discutiu-se tanto sobre o Cristo Histórico como agora" (Idem, Ibidem, p.22).

\title{
2. Deus e Jesus Cristo como motivos épicos: reflexões teórico-críti- cas
}

O americano Joseph Campbell (1904-1987) nos convida a pensar em "Deus" a partir do enfoque lexical e semântico:

\begin{abstract}
Como é possível despertar vida nova através de palavras ou formas míticas que, pelo uso, foram cristalizadas em um contexto de associações indesejadas? Tomemos por exemplo a palavra "Deus". Normalmente, quando ouvimos esse monossílabo o associamos, de um modo ou outro, com a ideia de "Deus" da Bíblia. Proferido na Índia, porém, normalmente não suscita essa associação. Usando a mesma palavra para um deus grego, um deus navajo, um deus babilônico - e são todos tão diferentes entre si que a palavra, empregada dessa forma curta e seca, não tem significado algum. De alguma maneira, essa palavra precisa ganhar um novo significado a cada vez que for usada (CAMPBELL, 2001, p.149).
\end{abstract}

Sua colocação é perfeita como ponto de partida porque descontrói imediatamente a ideia de que "Deus" é uma categoria bíblica. Ao contrário, o valor plurissignificativo da palavra precisa ser considerado para que, a partir dessa consideração, se reconheça a importância de situar esse "Deus" no contexto religioso ou apenas místico de que se queira falar. Em 2004, na tese Vozes épicas: história e mito segundo as mulheres, apontei alguns aspectos que permitem o "reconhecimento" do valor semântico do Deus hebraico e cristão, traduzido não só no texto bíblico como também em representações culturais de sua imagem mítica:

Javé - para os hebreus descendentes de Israel, povo escolhido e encarregado de realizar o projeto de Deus na Terra - ou Eloah, ou simplesmente Deus-Pai, na perspectiva do Novo Testamento, é culturalmente referenciado na forma masculina, branca, aloirada, musculosa, de aparência semelhante à de Zeus ou Júpiter. No entanto, na Bíblia nada há que indique especificamente uma "fisionomia" divina, ao contrário, em suas conversas com 
Moisés, Javé alude ao fato de jamais poder ser visto sem que isso cause a morte de quem o contemplasse. Todavia, difundida pelas artes em geral, essa imagem divina, provavelmente oriunda da presença do "Ancião" no sonho de Daniel (Daniel 7: 9-14), impregnou-se na cultura ocidental e é um caso típico de circularidade cultural (RAMALHO, 2004, p.288).

Tratei, pois, como "circularidade cultural"8 da imagem mítica de Deus o fenômeno de se reproduzir o Deus ancião e rigoroso juiz como visão única, de modo a cristalizar na sociedade ocidental as bases patriarcais que orientavam ou sobredeterminavam o comportamento humano.

Assim, quando se pensa na literatura como instrumento para a perpetuação ou para a negação dessa imagem cristalizada, deve-se considerar em que medida o texto em si está permeado ou não pela ótica patriarcal, opressora e mesmo violenta inerente a essa imagem. Nesse sentido, Ferraz comenta ter sido José Saramago "um escritor contemporâneo obcecado pelo tema Deus" (2008, p.26). Salienta, ainda, que

No decorrer de sua obra, destrói progressivamente as várias faces de Deus. Em Terra do Pecado (1945), ataca Deus de Eva e do pecado carnal; em História do cerco de Lisboa (1989), condena Jeová/Alá pelas guerras In nomine Dei; em Memorial do convento (1982), investe contra o Deus da Igreja Católica; em O Evangelho segundo Jesus Cristo (1991), reescreve um evangelho particular, concebendo um Deus cruel que quer ampliar seus domínios e necessita de um mártir para impressionar as pessoas (2008, p.26).

Instigada pela alusão a Saramago, cabe, no recorte pretendido, pensar (e surge a segunda questão): como Deus aparece em um texto como o épico, cuja natureza muitas vezes próxima do laudatório, aborda eventos históricos e míticos com o intuito de demarcar uma identidade cultural que tanto pode estar restrita ao local como atingir valor mais universal?

Sobre a imagem de Jesus Cristo, recorro a outro pensamento de Ferraz: "Existe uma diferença entre o Cristo Histórico e o Cristo da Fé. O Cristo da Fé, o Cristo Teológico, o Cristo Messias e Redentor é aquele que não precisa ser legitimado pela pesquisa histórica" (2008, p.22). Assim, entende-se que, no campo específico da Fé, a imagem mítica de Cristo é apenas mítica. Seu teor histórico prescinde de confirmação. Acredita-se em sua existência histórica a partir da própria crença em sua existência divina. Literatura, entretanto, não é religião. Não é texto estritamente religioso, ainda que possa ter vínculos com a religião. E a epopeia, por si mesma, ao integrar história e mito, não pode, portanto, prescindir da história. Nesse sentido, a presença de Jesus, quando a visão religiosa configura uma ideologia a embasar a criação, caberia apenas no plano maravilhoso de um poema épico? Eis a terceira pergunta.

Também em Vozes épicas: história e mito segundo as mulheres, eu trouxe à tona a discussão sobre o caráter épico de Jesus Cristo e cheguei a afirmar que ele seria "o herói épico natural mais importante do Ocidente e, por que não dizer, do mundo” (2004, p.312). A própria datação do tempo ocidental e, sob certa ótica, igualmente oriental, definida pelo "Antes de Cristo" e "Depois de Cristo" ratifica essa importância e já acentua a inserção de Jesus no plano histórico ou na cronologia da vida real. Se vivemos, portanto, na era "Depois de Cristo", a figuração histórica de Jesus é fato, não apenas crença.

\footnotetext{
8 Termo criado para nomear as constantes estagnações do caráter plurissignificativo de uma imagem mítica que decorriam de uma intencionalidade ideológica de perpetuar determinadas visões dessa imagem, tal como se deu com a sustentação patriarcal do Deus bíblico.
} 
Por outro lado, seu nascimento virginal, o fato de pertencer à $77^{a}$. geração de Israel, a superação das tentações do deserto, seus milagres, a Santa Ceia, sua crucificação e sua ressurreição, somados ao fato de ele próprio jamais ter escrito os textos de suas pregações projetam largamente a figura de Cristo no campo do maravilhoso e, por isso, permitem múltiplas leituras e materializações artísticas e ritualísticas, assim como originarão diversas religiosidades cristãs.

Gnósticos, essênios, docetas, ebionitas, maniqueístas e ofitas, por exemplo, cujos pensamentos foram deixados de lado a partir da definição do cânone católico, compreendiam e difundiam a imagem e a "história" de Jesus Cristo a partir de sentidos próprios, em muitos aspectos até divergentes. A obra Apócrifos: os proscritos da Bíblia (1992), que reúne os textos compilados por Maria Helena de Oliveira Tricca: Livro dos Segredos de Enoch; Livro da Ascenção de Isaías; Proto-Evangelho de Tiago; Evangelho Pseudo-Tomé; Evangelho Árabe da Infância; Excertos do Evangelho Armênio da Infância; Livro da Infância do Salvador; A História de José o Carpinteiro; Evangelho de Nicodemus e Descida de Cristo ao Inferno; Evangelho de Cartolomeu; Evangelho de Pedro; e Evangelho segundo Tomé o Dídimo, é um exemplo contundente de como a imagem de Cristo foi tomada a partir de diferentes concepções e enfoques.

Na própria Bíblia, temos compreensões particulares, tal como se vê nas "Cartas de São Paulo", em que Cristo é tratado como o "Segundo Adão", "ou seja, um Adão restaurado, no estado anterior à queda, quando tinha em si o Espírito de Adonai, seu pai, e de Shekinah, sua mãe" (1992, p.18). Por isso,

A fragmentação da imagem de Cristo, nos rituais e nas manifestações discursivas em geral, em Menino Jesus, Cristo Pregador, Cristo Crucificado e Cristo Ressuscitado fez-se recurso retórico para reflexões isoladas sobre os diferentes significados impressos em cada uma dessas imagens. Contudo, a unicidade de Cristo sustenta-se em sua personalíssima filiação a Deus (2004, p.315).

Uma obra muito interessante que apresenta, visualmente, a diversidade de imagens relacionadas ao Cristo do "Pantocrator" - o Cristo adulto, representado apenas na forma de "busto, com o livro ou rolo sagrado em uma das mãos e a bênção feita com a outra mão que, em geral, apresenta a representação das iniciais seu nome - e ao Cristo do "Mandilion" (a face de Cristo impressa numa "toalha") é Os ícones de Cristo (1977), de Georges Gharib. Nela o autor reproduz uma série de imagens, com datas entre o século IV e o XX, em que a representação física de Jesus, que, de certa forma, configuraria sua inserção no plano histórico, é muito diversificada. O tom da pele e dos cabelos, a cor dos olhos, os traços fisionômicos, em geral, ou têm correspondência com a cultura na qual a imagem foi produzida ou ratificam a inserção da obra em uma tradição estética específica. Gharib reproduz, ainda, uma imagem do Cristo menino, o "Emanuel", relevando como é ainda maior a complexidade da questão da plurissignificação da imagem mítica de Jesus.

Dito tudo isso, passemos às obras e ao reconhecimento, ainda que ligeiro, do modo como a essas duas imagens, a de Deus e a de Cristo, foram relacionados os planos histórico e maravilhoso das epopeias em foco.

\section{Deus e Jesus Cristo em cinco epopeias}

O poema A saga de Mem de Sá ou De Gestis Mendi de Saa (1563), de autoria do jesuíta espanhol a serviço de Portugal, José de Anchieta (1534-1597), tal como dissemos no segundo volume de História da Epopeia Brasileira (SILVA; RAMALHO, 2015), inaugura o 
percurso da épica brasileira. Com influência da Eneida, a obra se divide em quatro livros e faz uso do hexâmetro, para contar os feitos de Mem de Sá, com destaque para a guerra contra os índios no Espírito Santo e na Bahia e para a tomada do forte de Villegagnon, no Rio de Janeiro, o que configura o plano histórico do poema.

Com evidente ponto de vista religioso, a epopeia conduz os fatos sustentada também pela ótica do colonizador, que ganha relevo pela aderência da dimensão mística cristã impressa no processo de colonização no Brasil, evidente desde a dedicatória (intitulada, no poema, "Epístola Dedicatória”), que é “assinada” por Jesus Cristo e tem como destinatário Mem de Sá. Em síntese, posso adiantar que:

O poema, na verdade, tem dois heróis, Cristo Rei, o herói do plano espiritual, e Mem de Sá, o herói humano do plano material. Daí a invocação a Jesus, encarnação divina do Cristo, que faz a ligação dos dois planos, fundindo os feitos espirituais do Cristo Rei com os históricos de Mem de Sá, firmando uma aliança de Deus com o herói humano, de acordo com a interpretação agostiniana da história em $A$ Cidade de Deus (2015, p.55).

O recurso utilizado por Anchieta, para imprimir a desejada tonalidade cristã-católica aos fatos históricos narrados, é conjugar as ações celestiais e terrenas de modo tal que as segundas sejam sustentadas pelas primeiras, ou seja, "a ação dos seres espirituais se faz sentir no estado de ânimo dos combatentes, infundindo coragem, orientação e força ao herói e seus soldados; e medo, desorientação e terror às hostes inimigas" (2015, p.60). O Cristo tomado por Anchieta é o Cristo-Rei guerreiro que conta com as falanges angelicais para lutar contra os demônios. Logo, ocorre um paralelismo entre as figuras demoníacas enfrentadas por Jesus; os índios, tomados como inimigos ferozes e destituídos de Deus; e os franceses, tidos como invasores vis.

Esse paralelo espelha a "glória" dos feitos de Sá nas glórias celestiais alcançadas por Cristo, e a comemoração da vitória de Sá é justificada pela cristianização dos índios, tal como se vê em: "que harmonia nas cordas da cítara! que hinos contentes / cantastes ao Pai celeste! com que salmos sentidos/ exaltastes ao som da harpa as glórias de Cristo:/quando o índio começou a trocar sua ferocidade/por modos mais humanos e a conhecer o nome do Eterno!" (1986, p.135); ou em: "Dizei vós as leis e a ordem que o ilustre e piedoso/governador implantou entre povos tão feros,/para afinal ser honrado nestas paragens incultas/o nome vitorioso, forte e imortal de Jesus! (Ibidem, p.135-6).

Para compor esses dois planos, Anchieta, como estratégia do plano literário da obra, recorre à Bíblia, reapresentando os eventos de modo a ressaltar a imagem de um Deus onipotente, que: "criador do universo e da vida, e sua intervenção protetora no mundo para trazer de volta ao seu reino a criatura que tem sua imagem e semelhança" (2015, p.62). Cristo, como o filho herói que realiza os desígnios do Pai vence as hostes diabólicas ao mesmo tempo quem Sá vence seus inimigos, recurso que, como foi dito, projeta Sá no maravilhoso, aproximando-o, por semelhança de ações, ao próprio cristo. O plano maravilhoso, a partir desse recurso, é cristão e está apto a sustentar o discurso colonizador do plano histórico.

Outra aproximação que o poema faz é entre Mem de Sá e Moisés. Vencidos os índios e os inimigos franceses, Sá, como Moisés, é o portador da "nova lei". A violência da realidade histórica é substituída pela valorização de Sá como um "emissário" de Deus", que é, finalmente, reconhecido como tal pelos índios: 
O piedoso Mem de Sá desejou depois disto

ver adorado o Senhor do céu, do mar e da terra

e venerado nas plagas do Sul o nome de Cristo.

Resolve impor leis aos índios que vivem quais feras

e refrear seus bárbaros costumes. Logo desterra

a antropofagia cruel: não permite mais que movidos

de gula infrene bebam o sangue fraterno,

nem mais se violem os santos direitos da mãe natureza

e as leis do Criador. [...] (1986, p.131)

"Vencidos, pedimos paz: já não recusam os ombros

o peso da sujeição. Dá-nos a paz, nós to pedimos, ó Chefe!

Impõe-nos as leis que quiseres, que nós as cumprimos."

(Ibidem, p.183)

Como o próprio título em latim (língua original do poema) indica, a obra trata-se, pois, de uma "gesta" e, como tal, narra os feitos bélicos para, somente no final, assumir uma tonalidade mística que traz a religiosidade cristã para o primeiro plano. E "o poema termina com um hino de agradecimento, louvor e glorificação de Cristo Rei, enumerando todos os seus feitos, desde o passado da queda de Adão e Eva até os feitos recentes" (2015, p.75-6).

Por tudo o que foi dito, o histórico extermínio indígena não era, na perspectiva do poema, um objetivo da gesta narrada, mas sim uma decorrência necessária para o cumprimento de uma "missão colonizadora" que vê a cultura indígena como bárbara e demonizada, carente, assim, de uma interferência "purificadora". Por isso, em alguns trechos do poema ocorre também a valorização dos nativos que se submetem ao jugo do Catolicismo e passam a frequentar a missa e a realizar os rituais católicos. Além disso, cabe dizer, Anchieta deixa um legado de informações sobre a cultura indígena, fornecendo uma "descrição detalhada dos costumes indígenas, da organização econômica e social das tribos, de suas construções e vestimentas, de suas armas e táticas de luta" (2015, p.78). Curiosamente, será o próprio Anchieta herói de uma epopeia muito posterior à sua, tal como veremos mais adiante. Passemos à obra da portuguesa Soror Maria de Mesquita Pimentel.

Memorial da Infância de Cristo e Triunfo do Divino Amor, da monja portuguesa Soror Maria de Mesquita Pimentel (1581-1661), que constitui a primeira parte de uma trilogia voltada para a história de Jesus Cristo, foi publicada em 1639 , e indica, desde o título, que o herói épico do poema, nesse livro, será Jesus Menino. Segundo Fabio Mario da Silva, compilador da obra, com duas partes da trilogia por ele publicadas (2016 e 2017), os dados biográficos da autora são incertos, ainda que haja algumas datações e informações definidas por pesquisadores. No entanto, independentemente da precisão desses dados, é de se destacar, inicialmente, o fato raríssimo de uma mulher, em pleno século XVII haver escrito uma epopeia.

Como Pimentel era uma monja, podemos inferir, em uma impressão prévia, que a obra se trata, especificamente, de uma epopeia religiosa. E igualmente podemos imaginar que a ideologia que sustenta o plano literário do poema é a cristã católica. Logo, não se espera que o poema desconstrua a imagem mítica de Jesus Cristo, mas, sim, que a reafirme, em tonalidade visivelmente religiosa. Entretanto, ao abordar a infância de Cristo como matéria épica, Pimentel, conforme assinala Silva, não se restringe ao contexto bíblico. Vejamos:

\footnotetext{
${ }^{9}$ Silva (2016) informa que outros dois tomos foram publicados, um abordando os milagres de Cristo e outro abordando sua Paixão.
} 
Soror Maria de Mesquita Pimentel (1581-1661) (cf. MACHADO, 1752, p. 427), primeira mulher a escrever e publicar em língua portuguesa uma obra épica, nos relata, por causa do seu contexto monástico, a história da infância de Cristo, através da obra Memorial da Infância de Christo e Triumpho do divino Amor (1639), mas fá-lo não apenas sob a ótica religiosa pois traz para a sua narrativa os deuses da mitologia greco-romana (2007, p.2).

Além disso, também no âmbito do plano literário, Silva explica que:

Pimentel claramente procurou implantar passagens autênticas da Bíblia - como, por exemplo, a vinda dos três Reis Magos para adorar o menino-Deus; a sua apresentação no Templo, de acordo com o ritual da Torá; o massacre dos primogénitos em Belém; a fuga da Sagrada Família para o Egito - ficcionalizando-os a um grau que os associa com a intervenção de seres imaginários $(2017$, p.4).

Como se vê, a autora foi além da impressão óbvia que poderia cercar uma epopeia facilmente reconhecida como religiosa. Tendo como "musa inspiradora" a própria Virgem Maria e inserindo o contexto bíblico por meio da presença de anjos e demônios e da alusão a episódios da Bíblia, Pimentel, segunda Silva, não abandona, contudo, os referentes clássicos e deles faz uso, no decorrer do poema, como forma de realçar sua intencionalidade épica, enriquecer a imagética do poema e, ao mesmo tempo, filiar-se a uma tradição. A inventividade do plano literário da obra confere, ainda, às personagens femininas um protagonismo até então inexistente no âmbito da escrita épica.

Em Memorial da Infância de Cristo e Triunfo do Divino Amor, que reúne dez cantos, encontramos um "Prólogo ao leitor" que, funcionando como uma primeira proposição épica10, descreve e explica a matéria épica do poema:
A infância gloriosa
Do minino triunfante,
Que não teve semelhante,
Na grandeza poderosa
De ab initio Deus amante.
Em aplausos de memória
Vou dou leitores prudentes,
Mistérios de tanta glória,
Festejai-os sapientes,
Celebrai tão alta história. (2016, p.86)

A ideia de "infância triunfante" será construída a partir de uma remontagem da própria origem bíblica do mundo. Deus também figurará, por isso, no poema, como criador do mundo e do ser humano. No entanto, no poema de Pimentel, será um Deus capaz de ouvir a voz da "Misericórdia" e, principalmente a do "Amor divino", não punindo Adão, por isso, com a morte após o "pecado original”. Pimentel, assim, valoriza os laços de Deus com o Amor, o que, em plano século XVII também se pode considerar uma ousadia criativa, dadas as circunstâncias inquisitoriais então presentes no mundo ibérico.

Todos os demais cantos são permeados de diálogos e cenas que primam pela delicadeza e pela força de argumentos que valorizam a imagem de Virgem Maria e de José; apresentam o nascimento do "Deus sempiterno" (2016, p.173), Jesus; sua circuncisão; o choro da Mãe que vê o sangue derivado da circuncisão; a adoração dos reis magos; a perseguição de

${ }^{10}$ No Canto I outra proposição surgirá, na primeira oitava, ratificando a matéria épica. 
Herodes e a morte dos primogênitos; a aparição do anjo a José; a partida para o Egito; e as primeiras informações sobre a personalidade do Cristo Menino. No entanto, ao usar como recurso imagens metafóricas que dialogam com a tradição clássica, fazendo surgir personagens mitológicos e entidades abstratas, o poema costura os referentes históricos e míticos com muita homogeneidade, de modo tal que as fronteiras entre o sagrado (a divindade da pequena família) e o profano (a realidade simples da pequena família, captada em detalhes como o choro de Maria diante da circuncisão de seu bebê) não são percebidas, porque se diluem nos caminhos do simbolismo assumido, por exemplo, por figurações como a da Sapiência acompanhada por ninfas. Assim, a inventividade do plano literário da obra aproxima mito e história, ampliando, nos dois âmbitos, os referentes que neles, tradicionalmente, se esperaria encontrar.

Antes de apresentar a epopeia de Fagundes Varela, concluo com um trecho que permite visualizar os recursos do plano literário da epopeia de Pimentel para fundir o maravilhoso pagão, o sagrado cristão e o enfrentamento histórico à perseguição sofrida pela pequena família composta por Maria, José e Jesus:

Nisto em trono de estrelas aparecem

A Sapiência e ninfas tão fermosas,

As luzes do Varão, que resplandecem

Mais que as chamas de Febo luminosa:

De toda a companhia as glórias crescem,

Ouvindo as sete vozes deleitosas,

E juntas todas, como as aqui ferro,

Rodearam a Virgem do desterro. (2016, p.316).

Epopeia da última fase do Romantismo na Literatura Brasileira, Anchieta ou O Evangelho nas selvas, escrita em 1871, mas publicada em 1875, possui 8.484 versos decassílabos, organizados em dez cantos. É uma epopeia religiosa, que tem como matéria épica a evangelização dos indígenas brasileiros. No poema, o jesuíta José de Anchieta divide o protagonismo heroico com o próprio Jesus Cristo, uma vez que Fagundes Varela (1841-1875) aproxima as histórias de Cristo e de Anchieta como um recurso épico que permite a inserção de Anchieta no plano maravilhoso.

O poema, inicialmente, apresenta Anchieta já inserido no contexto da selva brasileira, cercado por índios, que, ao redor da cruz, preparam-se para ouvi-lo. Na descrição feita pelo eu lírico/narrador, Anchieta teria, naquele momento, 33 anos de idade, a primeira característica em comum com Jesus Cristo, recurso utilizado pelo poeta para unir os dois. A ênfase do poema está no Cristo Pregador e o paralelo que se estabelece é: assim como Jesus pregou para o povo de seu tempo, Anchieta pregará para os índios brasileiros, a fim de catequizálos.

$\mathrm{Na}$ estrofe X do Canto I do poema, a imagem do jesuíta é a do "apóstolo das selvas", outra forma de fazer a aproximação mencionada, que também comprova o enfoque na "palavra de Cristo" a ser matéria da fala do próprio Anchieta. Vejamos:

$\mathrm{X}$

Alma inspirada de Anchieta ilustre,

Espírito do apóstolo das selvas!

Sábio e cantor, luzeiro do futuro!

$\mathrm{Tu}$, que nas solidões do Novo Mundo

Sobre as alvas areias borrifadas

Das escumas do mar traçaste os veros

https://periodicos.unifap.br/index.php/letras

Macapá, v. 8, n. 3, $2^{\circ}$ sem., 2018 
Do - Poema da Virgem - e ensinaste

Aos povos do deserto a lei sublime

Que ao Reino do Senhor conduz os seres,

Ensina à minha musa timorata

A linguagem celeste que falavas! (1957, p.40-1)

Anchieta, portanto, será o porta-voz da palavra cristã, assumindo tanto a função de contar a trajetória de Cristo, segundo o Novo Testamento, quanto convencer os índios da importância de se renderem à fé cristã. Além disso, como se vê no trecho, é a palavra de Anchieta que ensinará à musa épica a "linguagem celeste" que o poema deverá ter.

Em relação à história sagrada ou bíblica, o Canto VII (com 18 estrofes) contém: a chegada de Jesus a Jerusalém; a salvação do povo para Jesus; a rejeição dos fariseus; a violenta reação de Jesus ao comércio no templo; a profecia que Jesus faz de sua própria morte; uma manifestação da voz de Deus pelo trovão; perguntas e provocações dos escribas, fariseus e sacerdotes para Jesus; o episódio da figueira estéril; o resumo feito por Jesus dos Dez Mandamentos que se convertem em apenas dois. Este último trecho se vê em:

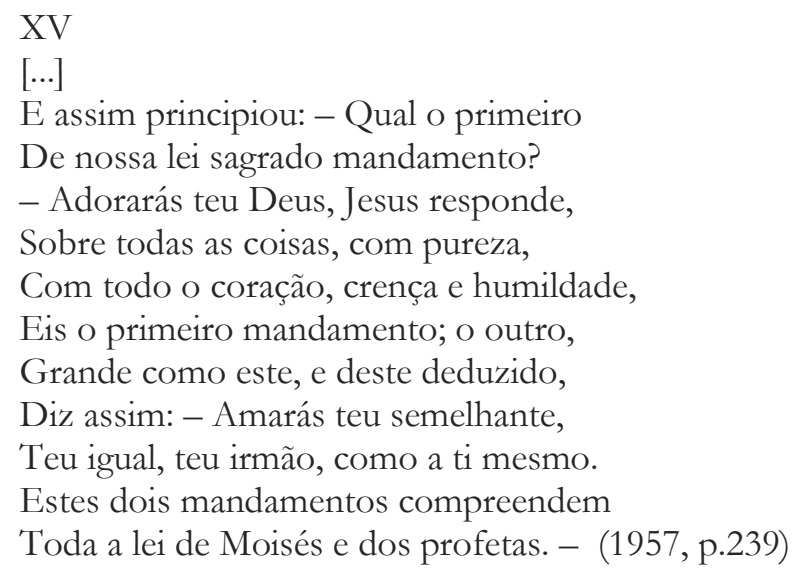

O Canto X, por sua vez, se refere aos últimos momentos de Anchieta, localizando temporalmente a história em 1577. O eu lírico/narrador compara Anchieta a João Batista e o chama novamente de "apóstolo da selva". Todos estão desanimados com a doença do jesuíta, que, na estrofe IV, fala novamente e faz uma descrição profética da terra independente do Brasil; compara Guanabara a Adamastor; lista outros jesuítas mortos e lhes dá o status de heróis; e revela a chegada do seu último momento, anunciando a visão de João Batista, Pedro e Paulo.
IX
Volve a teu negro exílio de amarguras,
Ó desgraçada musa! Às turvas ondas
Do temeroso mar, onde rebramam
As fúrias das procelas populares,
Entrega o pobre esquife, onde guardaste
Teus mais formosos e adorados sonhos!...
Adeus! Nossa missão está completa! (1957, p.326)

Pode-se perceber, através da comparação com a epopeia do próprio Anchieta, que o recurso de aproximar Cristo do herói humano é também utilizado por Varela, sem que se mantenha, contudo, o implícito caráter bélico da imposição do catolicismo aos indígenas 
de $A$ saga de Mem de Sá. Sigamos com a epopeia moderna Christ.

Christ (1965), poema épico moderno com 7.000 versos, de autoria do inglês de Worcestershire, Gavin Bantock (1939), estrutura-se em vinte e seis partes, cada qual iniciada, ordenadamente, por uma letra do alfabeto, tem como matéria épica, tal como o título aponta, a vida de Jesus Cristo. Em 2016, o autor publicou nova versão, com modificações que, segundo ele, geraram uma nova obra ${ }^{11}$. $\mathrm{Na}$ introdução ao livro de 1965, assinada por Syed Akbar Husain, já encontramos pista importante quanto à significação de Cristo no poema: "Thus, the poet declares his intention early on in the poem and makes na especial appeal to the reader do approach this work without prejudical notions either about Christianity, or the story of Jesus Christ as set out in the New Testament" (1965, p.ix) ${ }^{12}$.

A obra enfoca, especificamente, o que Husain chama de "missing years of Christ's life" [os dias perdidos da vida de Cristo] (Ibidem), apresentando cenas ligadas à relação de Cristo com João (o discípulo tido como o mais amado), com Maria Madalena, com a falibilidade da natureza humana e com sua própria falibilidade. Husain compreende o poema como uma visão do amadurecimento de Cristo através do tempo, em uma jornada para a "selfperfection" [autoperfeição] (Ibidem).

Negando o nascimento virginal e a visão de Cristo como Deus encarnado, Bantock, como comentei na introdução, propõe um épico que descontrói a tradição bíblica, para tomar o heroísmo de Cristo a partir de uma perspectiva histórica ficcionalizada, mas legitimada como ficção pelo fato de ser Cristo uma imagem mítica plurissignificativa. Assim, a obra parte de uma visão que nega o sagrado e toma Jesus Cristo como um homem falível, para, realçando aspectos de sua infância, defender a ideia de que: "Man must be the maker of his own destiny" [O homem deve ser o criador de seu próprio destino] (HUSAIN, 1966, p. $\mathrm{x}$ ), para fundamentar a mensagem final de que "one creed will be replaced by another, one God succeeded by another God, one stage in the Evolution of Man followed by another; but that in spite of all, men must continue to love and suffer" (Ibidem, p.xiii) ${ }^{13}$.

O plano maravilhoso do poema constrói-se a partir de presenças simbólicas, como a pérola, a gaivota/pássaro ou o pastor de ovelhas, e da inserção de referentes musicais que conferem ao ritmo do poema uma musicalidade igualmente simbólica. Na parte $\mathrm{C}$, a infância de Jesus é contada por um eu lírico/narrador em primeira pessoa, que é o próprio Cristo. Dividida em subpartes que vão de "A" a " $Z$ ”, essa parte elabora um “abecedário" da infância de Cristo, em uma perspectiva simultaneamente humana, lírica e metafórica, tal como se vê em:

Boy, beautiful boy, they said, as I, a boy, came running as a young stallion, calling to the wind, and my eyes singing to the light, and my feet on the unmoist land blasting dust as far-off storms in the brave and arid fields; and the world was not dark in eyes so unclouded as mine were then,

\footnotetext{
11 Ver: http:/ /www.brimstonepress.co.uk/books/detail/GB-Christos.htm.

12 “Assim, o poeta declara sua intenção logo no início do poema e faz um apelo especial ao leitor para que se aproxime dessa obra sem noções preconceituosas, nem sobre o Cristianismo, nem sobre a história de Jesus Cristo exposta no Novo Testamento". Todas as traduções apresentadas no corpo do texto ou em forma de notas são de minha autoria. 13 “um credo será substituído por outro, um Deus sucedido por outro Deus, um estágio na Evolução do Homem seguido por outro; mas que, a despeito de tudo, os homens devem continuar a amar e sofrer".
} 
as Rome came warring in $(1965, \text { p.23) })^{14}$.

Os quarenta dias no deserto são tratados de forma igualmente inovadora e simbólica, assim como a crucificação, que merece um poema visual, que referencia Judas Iscariotes, provendo a visão de que a cruz não encerra a história, que será feita de reencontros:

\section{ISCA R I O T \\ is gone from \\ our midst \\ yet he shall}

come across Jesus again whether

I be his David or his promised King

whatever, our roads shall cross,

our ways shall clash their beams

with my arms

spread wide

I greet him

from above:

I shall cross

him in the

east and west

while he goes

to and from

the poles.

$\left(1965\right.$, p.224) ${ }^{15}$

Assim, em Christ, temos um Jesus reinventado a partir de uma tradição épico-heroica já conhecida, que é descontruída como forma de valorizar o que os versos iniciais e finais do poema afirmam: "A men at the begginning of my love/for that is the beckoned theme"16 (1965, p.1) e "I am forever that singing gull in love's wake:/ now I know - that for criming men who adorn fields, / finish echoes in the wind when love beckons"17 (1965, p.251), ou seja: Cristo é, acima de tudo, Amor. Talvez por isso, o poema tenha sido republicado em 2016 (Unknown Publisher) com o título Christos: Lovesong of the Son of Man: A Poem in Twenty-Six Parts. Sigamos com outra epopeia que trabalha com as imagens de Deus e de Jesus Cristo, agora no contexto cabo-verdiano.

A cabeça calva de Deus (2001), trilogia épica do cabo-verdiano Corsino Fortes (19332015), que reúne Pão \& Fonema (1974); Arvore \& Tambor (1986) e Pedras de sol \& Substância (2001), traz, em seu próprio título o referente religioso, criando uma imagem que projeta a obra, desde o título, no contexto metafórico do "divino" que predominará em suas três

\footnotetext{
14 “Garoto, menino lindo, eles disseram,/como eu, um menino, vim correndo como um jovem garanhão,/chamando pelo vento,/e meus olhos cantando para a luz/e meus pés na terra sem moagem/soprando poeira como tempestades distantes/nos campos bravos e áridos;/e o mundo não era escuro nos olhos/tão sem nuvens como eram os meus então,/quando Roma chegou guerreando".

15 ISCARIOT/se foi de/ nosso meio,/mas ele deve/se deparar com Jesus novamente, quer/eu seja o seu Davi ou o seu Rei prometido,/nossas estradas se cruzarão,/nossos caminhos devem colidir seus raios/ com meus braços/abertos/Eu o saúdo/de cima:/eu vou cruzar com/ele no/leste e oeste,/enquanto ele vai e vem/para e dos/pólos".

16 "Um homem no começo do meu amor / desse modo é o tema acenado".

17 "Eu sou para sempre aquela gaivota que canta o despertar do amor/agora eu sei que - para os pecadores [ou criminosos] que adornam os campos, / terminam os ecos ao vento quando o amor acena".
} 
partes ou livros, sem, contudo, conferir à trilogia um caráter propriamente religioso. Como a análise busca sustentar, o que Fortes faz é projetar o próprio povo caboverdiano, suas histórias e seus mitos, no campo de um "sagrado" que não limita propriamente a experiência humano-existencial como o fazem as religiões, mas sim estrutura a resistência e o perseverar na luta como fundamento básico para se solidificar, cada vez mais, a independência e a identidade cultural de Cabo Verde. O sagrado, portanto, na obra é o próprio arquipélago. Assim, o que constrói a imagem do sagrado são trechos poéticos que evidenciam a presença implícita desse sagrado como composição mítica (e mística) do próprio chão da realidade cabo-verdiana.

Pão \& fonema, por exemplo, apresenta diversas alusões que remetem ao texto bíblico: "Aqui/ Ergo a minha aliança" (2001, p.85); "Este homem E a sua fêmea/ Tal tábua E o seu tabernáculo/ O sol na boca grávida/ O pão das artérias sobre a mesa" (Ibidem), que sugerem o par primordial, Adão e Eva, como fundadores do sangue da identidade caboverdiana. Em Árvore \& Tambor, por sua vez, temos trechos como " $\mathrm{Na}$ ilha! A cicatriz de deus é grande/ Mas a ferida do homem é maior /.../ A lírica de deus é grande/ Mas a música do homem é maior" (2001, p.128), em que o protagonismo da ação humana se destaca como superior a ação divina de um deus sem inicial maiúscula. Por isso, o trecho "Então! Saudamos o tambor e o versículo que chega/ No fim do dia E nomeia/ o seu povo e a sua lei/ entre o fogo de Eclesiastes/ e a parábola do Testamento de Amílcar" (2001, p.137), promoverá a fusão do Testamento bíblico com o Testamento histórico e literário do herói revolucionário Amílcar Cabral.

Em Pedras de Sol \& Substância, encontramos o poema "Rotcha scribida", que, "remontando à mais remota ancestralidade da terra, reinaugura, pois, sua fundação, atribuindo à pedra mítica e mística o papel de preservar a memória intraduzível da terra" (RAMALHO, 2017, p.232):

Ó rosto de mil lábios na tua crónica de milénio na tua letra \& sílaba a palavra inamovível

$/ \ldots /$

Ó bíblia de murmúrio na tua semântica

De sal! Sangue \& paradoxo

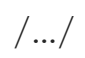

Pela maternidade Do versículo que nos une
$\mathrm{Na}$ tua chama
$\mathrm{Na}$ tua lava
No seu tambor inenarrável (2001, p.223).

A palavra "Deus" (também nas formas "deus" e "deuses") aparece 48 vezes na trilogia, contudo, as associações são diversas, tal como exemplificam essas aparições em Pedras de Sol \& Substância: "Estas ilhas que correm/ pela cabeça calva de Deus / À procura dos glóbulos brancos vermelhos/ o arquipélago inacabado" (2001, p.269), "o que incita à necessidade do envolvimento do próprio povo cabo-verdiano no compromisso de finalizar a obra 
divina, resgatando, pela palavra cabo-verdiana" (ramalho 2017, p.233); "Sons / que já foram deuses / E ainda habitam os pedregulhos o coração" (p.270) ou "Todos os dias! as mãos de Deus / Colocam um vulcão E um navio/ Entre os seios E as ancas/ De cada mulher" (2001, p.273). Assim, o Deus bíblico se dilui em um Deus/deus/deuses que aparece impregnado nas mais diversas circunstâncias dos planos histórico e maravilhoso do poema, libertado, pois, de uma religiosidade ritualística católica para ganhar uma significação mais ampla.

Por outro lado, a obra também apresenta muitas referências a Jesus. Na trilogia, "a figura de Jesus, a Santa Ceia, a hóstia, o vinho, a aliança, a fala de Cristo chamando a humanidade ao amor, tudo servirá para que, no poema, fique sugerida a fusão entre o humano e o divino" (RAMALHO, 2017, p.145):

Oh! Quando a manhã amanhecer

E Cristo descer da sua morada

E vier vindo

Para o braço direito do Monte Cara

Com seu cabo de enxada

E seus calções de drill

Com seus pés descalços

E seu dedo partido

E se sentar

Na pedra redonda do nosso fogão

Sem chuva na mão

Sem fraqueza no sangue

E sem um corvo no coração (Pão \& Fonema, 2001, p.91).

O Cristo, portanto, humaniza-se, espelhando o próprio cabo-verdiano, sentando-se com o povo na "távola redonda" cabo-verdiana. É um Jesus que não traz milagres nas mãos, mas cuja imagem infunde a motivação para o trabalho e a esperança na transformação da vida precária. Daí ser possível afirmar que: “A aliança de Deus com a terra (Gênesis, 9:13) propagada pela palavra de Cristo também é a palavra do poema, que, para ter força de representação, não pode prescindir da consolidação desse repertório vocabular identitário do humano em Cabo Verde". (RAMALHO, 2017, p.146), logo, por meio de um plano literário extremamente inventivo, Fortes descola Deus e Jesus de seus referentes bíblicos tradicionais, para compor, através de variada inserção de suas imagens no poema, a fusão entre a história dos cabo-verdianos e sua "predestinação" a fazer de Cabo Verde uma terra sublime e, por isso, capaz de dar um

Golpe de estado no Paraíso

I

Na História! $\mathrm{Na}$ Bíblia da nossa terra

Se a rocha é página! a pedra é sílaba

Se o corpo é caneta! o coração é tinta

Nem todos os desertos do mundo

Secarão as fontes e os poços que as nossas bocas abrirem

Nem trovões nem relâmpagos rasgarão

As páginas que o nosso povo escreveu

$\mathrm{Na}$ morada da nossa morabeza

Todo o Diabo perderá o seu inferno

E todo o navio perderá a sua bússola

https://periodicos.unifap.br/index.php/letras

Macapá, v. 8, n. $3,2^{\circ}$ sem., 2018 
No coração da nossa bonança (2001, p.209).

Feitas as breves análises, retomemos, já concluindo, as questões propostas nas duas primeiras partes deste estudo.

\section{Conclusão}

Inicio com a questão "A presença da religião em uma epopeia define, por parte de seu autor ou de sua autora, de certo modo, uma 'captação' e uma 'utilização' da 'energia do sagrado' em prol de um interesse ideológico? Se partimos do fato de que Anchieta e Soro Pimentel foram religiosos e como tal é que produziram literatura, é inevitável que entendamos que não poderiam se eximir de expressar em suas epopeias algo da ideologia cristãcatólica à qual se vinculavam por sua condição. Entretanto, é visível que, em termos de reconhecimento do plano literário de cada obra, Pimentel foi mais ousada, tanto no sentido de aproximar a visão de Deus e de Cristo à tônica amorosa como no de criar um protagonismo para personagens femininas não usual em seu tempo e no de explorar recursos estéticos próprios da tradição clássica pagã. Cabe, contudo, comentar o papel de jesuíta colonizador assumido por Anchieta, o que certamente fazia com que ficasse diretamente exposto às barbáries e às crueldades da cristianização dos índios. Daí, talvez, a necessidade de reforçar uma justificativa para a gesta narrada. Quanto aos outros autores, percebe-se, de um lado, o caráter contra ideológico de Bantock e a natureza extremamente inventiva da metafórica trilogia épica de Fortes, e, de outro, a preocupação de Varela em imprimir em seu texto uma ideologia compatível com a de seu herói, o que dez de sua epopeia uma epopeia, de fato, religiosa.

Quanto à segunda questão: "Como Deus aparece em um texto como o épico, cuja natureza muitas vezes próxima do laudatório, aborda eventos históricos e míticos com o intuito de demarcar uma identidade cultural que tanto pode estar restrita ao local como atingir valor mais universal?", podemos ratificar, através das análises feitas, como é pertinente a visão do caráter plurissignificativo de uma imagem mítica. O Deus bélico da epopeia de Anchieta é muito diferente do Deus aberto ao diálogo do poema de Pimentel, do Deus Pai da Santíssima Trindade que se vê na epopeia de Varela; do Deus negado no texto de Bantock e do Deus cabo-verdiano inaugurado por Fortes. Ainda que todas essas imagens se relacionem ao Deus bíblico, cada qual se apropria do referente Deus com uma intencionalidade literária diferente em termos de concepção do plano literário e de promoção da fusão entre mito e realidade. Bantock, por exemplo, "mata” Deus para poder nos fazer ver o Cristo Homem.

Quanto ao questionamento sobre a presença de Jesus Cristo, quando a visão religiosa configura uma ideologia a embasar a criação, caber ou não apenas no plano maravilhoso de um poema épico, é possível responder que não. Mesmo quando há uma ênfase na ideologia religiosa, pode-se ter a inserção de Cristo no plano histórico, tal como faz Pimentel, que valoriza a infância de Jesus Menino. Anchieta, por sua vez, aproxima Cristo da história ao elaborar um paralelismo entre suas ações e as de Mem de Sá. Igual procedimento reconhecemos na obra de Varela. De toda maneira, tal como se viu em relação à imagem de Deus, são muitos os "Cristos" que pudemos, sequencialmente, encontrar: o Cristo-Rei, o Jesus Menino, o Jesus Pregador, o Cristo Homem, o Cristo homem cabo-verdiano.

Muitas outras considerações poderiam ser desenvolvidas. Mas, dada a necessidade de chegar ao ponto final, espero ter deixado elementos suficientes para despertar o interesse 
pelo gênero épico e sua capacidade, sempre renovada, de potencializar o caráter plurissignificativo das imagens míticas de Deus e de Jesus Cristo. Fica o convite à leitura das cinco epopeias (ou releituras, quando as obras forem conhecidas pelos/as leitores/as).

\section{Referências}

ANCHIETA, José de. De gestis Mendi Saa. Poema Épico. Introdução, versão e notas do Pe. Armando Cardoso, S.J. Obras Completa s $-1^{\circ}$ volume. São Paulo, Edições Loyola, 1986.

Apócrifos. Os proscritos da Bíblia. Textos compilados por Maria Helena de Oliveira Tricca. São Paulo: Editora Mercuryo, 1992.

BANTOCK, Gavin. Christ. A poem un twenty-six parts. Oxford: Donald Parsons, 1966. CAILLOIS, Roger. O homem e o sagrado. Lisboa: Edições 70, 1979.

CAMPBELL, Joseph. Temas mitológicos na arte e na literatura criativa. In:

(Org).

Mitos, sonhos e religião. Nas artes, na filosofia e na vida contemporânea. Trad. Angela Lobo de Andrade e Bali Lobo de Andrade. Rio de Janeiro: Ediouro, 2001, p. 139-175.

FERRAZ, Salma. No princípio era Deus e ele se fez poesia. Rio Branco, AC: EDUFAC, 2008.

FERRAZ, Salma. Teopoética: os estudos literários sobre Deus. In: era Deus e ele se fez poesia. Rio Branco, AC: EDUFAC, 2008, p. 19-31.

No princípio FORTES, Corsino. A cabeça calva de Deus. Lisboa: Publicações Dom Quixote, 2001.

GHARIB. Georges. Os ícones de Cristo. História e culto. Trad. José Raimundo Vidigal. São Paulo: Paulus, 1977.

MILES, Jack. Cristo. Uma crise na vida de Deus. Trad. Carlos Eduardo Lins da Silva e Maria Cecília de Sá Porto. São Paulo: Companhia das Letras, 2002.

PIMENTEL, Soror Maria de Mesquita. Memorial da Infância de Cristo e Triunfo do Divino Amor (primeira parte). Organização, notas e estudos introdutórios de Fabio Mario da Silva. São Paulo: Todas as Musas, 2016.

RAMALHO, Christina. Vozes épicas: história e mito segundo as mulheres. Rio de Janeiro: UFRJ, 2004. Tese de Doutorado.

RAMALHO, Christina. A presença da Virgem Maria na epopeia brasileira. In: FERRAZ, Salma. No princípio era Deus e ele se fez poesia. Rio Branco, AC: EDUFAC, 2008, p. 86-96.

RAMALHO, Christina. A cabeça calva de Deus, de Corsino Fortes: o epos de uma nação solar no cosmos da épica universal. Natal: LucGraf, 2017. E-book.

VARELA, Fagundes. Anchieta ou O Evangelho nas selvas. In: Poesias completas de L. N. Fagundes Varela. vol. 3. Organização e apuração do texto por Miécio Táti e E. Carrera Guerra. São Paulo: Companhia Nacional, 1957, p. 31-326.

SILVA, Anazildo Vasconcelos da; RAMALHO, Christina. História da epopeia brasileira. Vol 1. Rio de Janeiro: Garamond, 2007.

SILVA, Anazildo Vasconcelos da; RAMALHO, Christina. História da epopeia brasileira. Vol 2. Aracaju: ArtNer, 2015.

SILVA, Fabio Mario da. O épico escrito por mulheres na Península Ibérica: Bernarda Ferreira de Lacerda (1595-1644) e Soro Maria de Mesquita Pimentel (1581-1661). In: Revista Épicas, Ano 1, N. 1, Jun 2017, p. 1-11. 